Casualties of Care 
This page intentionally left blank 


\section{Casualties of Care}

I M M I G R A T I O N A N D THE POLITICS O F H U M A N I TARIA N I M I N FRANCE

M I R I A M T I C K T I N

甲

U NIVERSITY OF CALIFORNIA PRES Berkeley Los Angeles London 
University of California Press, one of the most distinguished university presses in the United States, enriches lives around the world by advancing scholarship in the humanities, social sciences, and natural sciences. Its activities are supported by the UC Press Foundation and by philanthropic contributions from individuals and institutions. For more information, visit www.ucpress.edu.

University of California Press

Berkeley and Los Angeles, California

University of California Press, Ltd.

London, England

(C) 2011 by The Regents of the University of California

Library of Congress Cataloging-in-Publication Data

Ticktin, Miriam Iris.

Casualties of care : immigration and the politics of humanitarianism in France / Miriam Ticktin.

p. $\mathrm{cm}$.

Includes bibliographical references and index.

ISBN 978-0-520-26904-o (alk. cloth) — ISBN 978-0-520-26905-7 (pbk. : alk. paper)

1. Emigration and immigration-Government policy-France.

2. Humanitarianism-France. I. Title.

$\mathrm{JV}_{7925.2 . T_{53} 2011}$

$325.44-\mathrm{dc} 22$

2011008975

Manufactured in the United States of America

$\begin{array}{llllllllll}20 & 19 & 18 & 17 & 16 & 15 & 14 & 13 & 12 & 11\end{array}$

$\begin{array}{llllllllll}10 & 9 & 8 & 7 & 6 & 5 & 4 & 3 & 2 & 1\end{array}$

In keeping with a commitment to support environmentally responsible and sustainable printing practices, UC Press has printed this book on 50-pound Enterprise, a 30\% post-consumer-waste, recycled, deinked fiber that is processed chlorine-free. It is acid-free and meets all ANSI/NISO (z 39.48) requirements. 
For my parents, Marlene and Saul 
Illness is - as you say - the only way (Form) of life in capitalism.

Jean-Paul Sartre, letter to Socialist Patients' Collective, 1972 